\title{
Institutional isomorphism, entrepreneurship and effectiveness: the adoption and implementation of quality management in teaching and learning in Germany
}

\author{
Markus Seyfried $^{1} \cdot$ Moritz Ansmann $^{1} \cdot$ Philipp Pohlenz $^{2}$
}

Published online: 25 January 2019

(C) The Author(s) 2019

\begin{abstract}
This paper presents empirical evidence on the adoption, implementation and the perceived effectiveness of quality management in teaching and learning in German higher education institutions. Theoretically, the article combines two new institutionalist approaches: institutional isomorphism and institutional entrepreneurship. Empirically, the study refers to qualitative interview data and quantitative survey data. The analysis reveals that isomorphism is a leading driver behind the adoption of quality management in German higher education institutions, whereas institutional entrepreneurship plays an important role in quality management implementation. While isomorphism can be regarded as a conclusive reason behind the absence of a perception of quality management's effectiveness, institutional entrepreneurship may function as a corrective towards the overall negative impact of isomorphic conformity by institutionalizing quality management in a sustainable manner.
\end{abstract}

Keywords Higher education - Quality management - Quality assurance · New institutionalism · Isomorphism $\cdot$ Institutional entrepreneurship

\section{Introduction}

Quality in teaching and learning has always been a major concern in higher education. Until recently, the responsibility for cultivating a quality orientation had been assigned to individual lecturers as their personal obligation. Today, quality is subject to management supervision and

Markus Seyfried

seyfried@uni-potsdam.de

1 Potsdam University, Potsdam, Germany

2 Otto von Guericke University Magdeburg, Magdeburg, Germany 
is an organizational obligation assured by institutional quality management. This global trend is observable in almost every higher education system (Martin and Parikh 2017; Paradeise and Thoenig 2013; Woodhouse 1996, p. 355).

The rise of quality management is often regarded as a 'fashion' (Stensaker 2007) or a 'management fad' (Birnbaum 2000). In this regard, the diffusion of quality management appears to have a cumulative effect, with higher education institutions observing and imitating one another. Accordingly, some authors explain this development by pointing to strong institutional pressures (Csizmadia et al. 2008, pp. 449-450; Soomro and Ahmad 2012, p. 148; Stensaker 2008, p. 6). The respective findings draw very much on new institutional theory, specifically the seminal concept of institutional isomorphism introduced by DiMaggio and Powell (1983). They developed a theoretical approach to identify three types of institutional pressures. In their attempt to explain the remarkable similarity between organizational structures, they emphasized the crucial significance of coercive, mimetic and normative isomorphism in organizations. According to DiMaggio and Powell (1983, p. 150), the phenomenon that organizations resemble one another (isomorphism) can be attributed to legal or political regulatory pressures ('coercive'), copying behaviours resulting from organizational uncertainty ('mimetic') or normative pressures initiated by professional groups ('normative'), rather than to functionalistic strategies.

Due to its popularity, the theory of isomorphism has often been empirically tested and operationalized in many fields of organizational research (Mizruchi and Fein 1999). However, this perspective has not yet been applied systematically for empirical studies on the emergence of internal quality management in teaching and learning in higher education institutions. Specifically, evidence on the institutional meso and micro level is still rare. However, such a research gap needs to be closed, particularly because the phenomenon of isomorphism may be linked to the effects of quality management in teaching and learning. On a theoretical level, it can be deduced that isomorphism may induce negative effects of quality management in teaching and learning such as decoupling tendencies (Meyer and Rowan 1977; Westphal et al. 1997). Whereas consensus exists among institutionalists that isomorphism induces legitimacy benefits, there is reason to assume that isomorphism lowers substantive organizational performance and efficiency (Barreto and Baden-Fuller 2006).

In turn, whether it is possible to avoid such negative effects may depend on institutional leadership (Kraatz 2009; Selznick 1957; Washington et al. 2008). While isomorphism may be an external stimulus for the adoption of quality management, institutional entrepreneurship might be a key variable for the implementation of quality management and may be regarded as a counterforce to the perception of quality management as ineffective.

Based on this theoretical assumption, the present article empirically investigates the adoption, implementation and (perceived) effects of quality management in German higher education institutions. The focus is on examining the following research questions: what role did isomorphism play in quality management adoption, and how do isomorphism and institutional entrepreneurship relate to the perceived effectiveness of quality management? By answering these questions, the study contributes to the ongoing debate on the effects and impact of quality management (Stensaker 2008).

Empirically, we used qualitative interview and quantitative survey data from the $\mathrm{WiQu}$ research project which has investigated procedural, structural and personnel influences on the impact of quality assurance departments. Methodologically, we follow a mixed methods approach by combining qualitative and quantitative data (Kelle 2006; Tashakkori and Teddlie 2003). 


\section{Quality management in teaching and learning - The German case}

A recent survey study showed that quality management is already a reality in a majority of higher education institutions worldwide (Martin and Parikh 2017, p. 12). This also applies to German higher education (Kaufmann 2009; Seyfried and Ansmann 2018), even though Germany can be regarded as a latecomer in higher education reforms in general, compared to the rest of Europe. Relatedly, Schimank and Lange (2009) have referred to the New Public Management regime being installed rather late in Germany. In addition, due to the federal structure of the German higher education system, quality management was implemented at different times and with different approaches. It needed the Bologna Process, the corresponding implementation of an external quality assurance system and the resulting Standards and Guidelines for Quality Assurance in the European Higher Education Area (ESG) that brought about a comprehensive introduction of quality management in German higher education institutions.

Higher education institutions have been assigned the task of quality assurance, and have interpreted this as a strategic management task. Although elaborate quality management approaches such as, for example, total quality management still exist today at only a few higher education institutions, almost all institutions have at least established a central unit that provides various services regarding to the control, assurance and improvement of teaching quality (Kaufmann 2009; Pohlenz and Seyfried 2014; Seyfried and Ansmann 2018). Thus, it can be explained by the development that the German debate rarely differentiates between quality assurance and quality management. The latter is rather used as an umbrella term. Accordingly, in this paper, quality management is also rather broadly defined as 'the policies, systems and processes designed to ensure the maintenance and enhancement of quality within an institution' (Csizmadia 2006, p. 24),

\section{Theoretical approach}

Institutional theory has proved to be a powerful and popular explanatory tool for analysing organizational change and behaviour. Whereas classic approaches stress the idea that organizations are dominated by the role of individuals, rational actors and their personal preferences and interests, new institutionalism very much emphasizes the formative role of institutions. The core postulate is that organizational actors always pursue their interests within certain institutional constraints (Greenwood et al. 2008). From this point of view, patterns of organizational actions are shaped more by institutional forces, such as cultural scripts and norms, than by instrumental calculations (DiMaggio and Powell 1983; Meyer and Rowan 1977). Organizations are here considered as deeply embedded in social environments, suggesting that organizational procedures and structures are often reflections of environmental expectations. Subsequently, institutional theory assumes that organizations try to react to the demands of their institutional environment to gain legitimacy (Meyer and Rowan 1977).

\section{Institutional isomorphism}

When considering organizational change and adaptation in institutional theory, it is essential to refer to the seminal approach of institutional isomorphism advanced by DiMaggio and Powell (1983). DiMaggio and Powell developed an explanation for organizational change based on 
the concept of homogenization and convergence through institutional pressures. Hence, institutional isomorphism may be regarded as a theoretical approach that describes how 'systems of organizations become more and more alike' (Rhoades and Sporn 2002, p. 356). DiMaggio and Powell (1983, p. 147) conclude that organizational change is less and less inspired by 'competition' or 'by the need for efficiency'. Instead, the authors identify three main mechanisms that lead to institutional convergence; namely, coercive, mimetic and normative isomorphism (DiMaggio and Powell 1983, p. 150).

In DiMaggio and Powell's (1983) view, coercive isomorphism stems from external expectations of organizations' legal and cultural environment as well as political influence, conveyed through laws and regulations. Whenever laws are passed that regulate organizational structures and procedures, they simultaneously create expectations and pressure for organizations to comply. Mimetic isomorphism emerges from organizational uncertainty and ambiguity. Organizations are constantly encountering problems, and techniques on how to solve them are often unclear. Thus, it is a reasonable strategy to survey how comparable organizations cope with challenges. In such cases, organizations simply copy seemingly adequate modes of problem solving without much reflection. Normative isomorphism stems from the values of professionalism and the emergence of legitimate professional practices that result in normative pressure. Normative isomorphism is predominately associated with the organizations' members, their educational or professional background and their interest in promoting professional norms. The growth and expansion of networks as providers of new ideas, models and narratives are of great importance in this context (DiMaggio and Powell 1983, p. 152).

Our basic thesis is that processes of isomorphism in quality management adoption may be linked to the impact and perceived effectiveness of quality management. In this regard, we follow the study by Barreto and Baden-Fuller (2006), which showed that isomorphic conformity enhances the symbolic performance yet it is negatively associated with substantive performance. Hence, in some cases, coercive isomorphism may lead to formal compliance but not to actual change (Meyer and Rowan 1977). By fulfilling external requirements, organizations have different strategies ranging from real change to the creation of 'rational myths' (Meyer and Rowan 1977, p. 346). The latter is particularly relevant in times of ambiguity, complexity and insecurity. Hence, if quality management has been introduced because of external pressures and for the sake of gaining legitimacy, we can presume a perception of a less effective quality management. Consequently, we can further assume that, in such organizations, quality management may be confronted with problems of implementation. In contrast to coercion and mimesis, normative isomorphism is related to conviction and a change of actors' mindset. Thus, it may induce positive effects.

\section{Institutional entrepreneurship}

The concept of 'institutional entrepreneurship' has become very popular in institutional theory as institutional scholars have increasingly been faced with the challenge of explaining the central role of individual agency in institutional change (DiMaggio 1988; Greenwood and Suddaby 2006). Following DiMaggio's (1988) early work, the notion of institutional entrepreneurship refers to 'activities of actors who have an interest in institutional arrangements and who leverage resources to create new institutions or to 
transform existing ones' (Maguire et al. 2004, p. 657). Thus, the focus of institutional entrepreneurship literature is on the mechanisms that enable entrepreneurs to shape their institutional environment from within. In this regard, Battilana et al. (2009) assume that institutional entrepreneurs enforce changes by creating a vision for change, mobilizing resources and motivating others to achieve and sustain the vision. Institutional entrepreneurs are predominantly those actors who adopt leadership roles in organizations; institutional leaders play a decisive role in organizational change and institutionalization processes. These assumptions also hold true for the implementation of quality management in teaching and learning. Functioning as 'institutional entrepreneurs' (DiMaggio 1988; Greenwood and Suddaby 2006), a higher education institution's leadership can play a crucial role in promoting 'institutional quality work' by actively engaging in the relevant institutionalization process and by introducing quality management in spite of initial resistance (e.g., from individual scientists and/or lecturers). By doing such 'institutional work' (Lawrence and Suddaby 2006), leaders may be able to shape the institutional set-up of quality management and make it more impactful. In short, only if quality management is supported by the leadership will quality managers be able to do their institutional work and adapt quality management to the existing organizational context.

To sum up, we applied the concept of institutional isomorphism in combination with an institutional entrepreneurship perspective (see Fig. 1). By doing so, we built a bridge between the first wave of new institutionalism, which was characterized by a rather deterministic view of institutionalized action, and more recent approaches, which call for an agentic direction in institutionalism (Hirsch and Lounsbury 1997). The thesis was that, under certain conditions, institutional entrepreneurship may function as a corrective towards isomorphic pressures and help institutionalize quality management without negative externalities such as decoupling and formal adaptation.

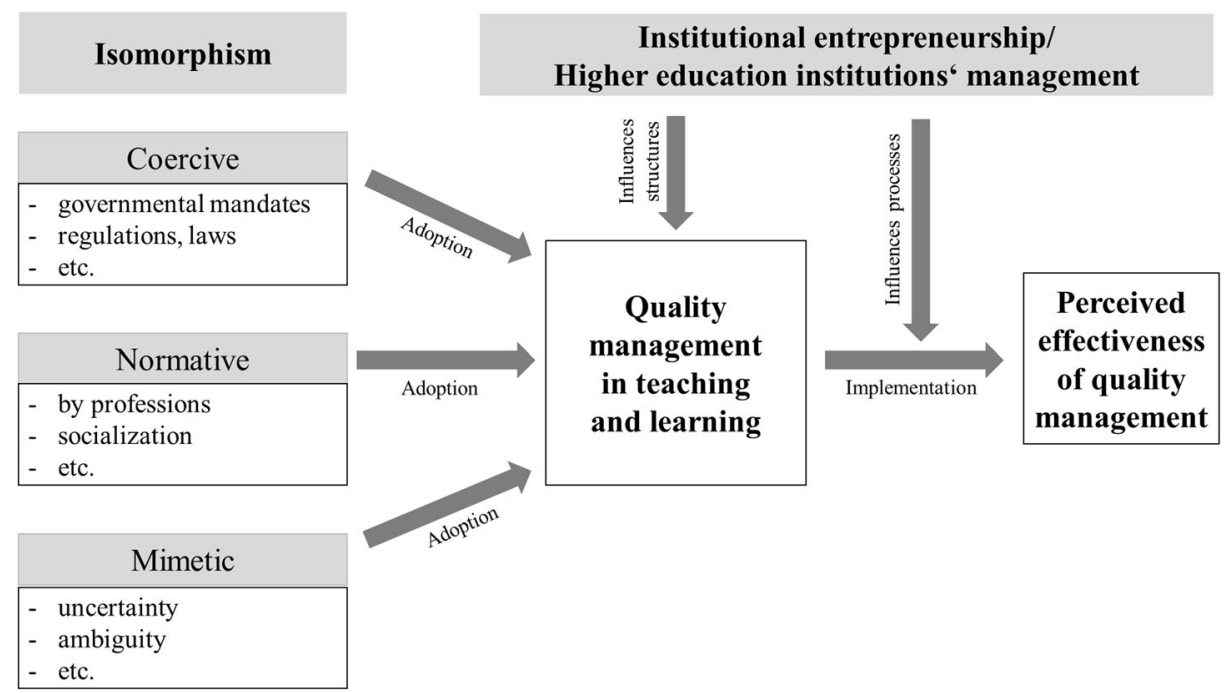

Fig. 1 Interaction of isomorphic pressures and entrepreneurship 


\section{Data and methods}

This study utilized a mixed methods research design combining qualitative and quantitative data (Kelle 2006; Tashakkori and Teddlie 2003). Quantitative survey data were used to provide a general overview and the results were contextualized with qualitative data from an interview study (Sandelowski 2000, p. 335), which provided more detailed information.

The present study refers to data from semi-structured interviews that we conducted with quality management staff in German higher education institutions in 2014 and 2015. In total, we conducted 56 interviews at 23 universities and universities of applied sciences (Fachhochschulen) with actors in charge of quality management in teaching and learning (e.g., quality managers, vice presidents for teaching and learning, deans of studies). The criterion of case selection was based on achieving maximum variance among the higher education institution population in order to avoid selection bias in terms of size and academic discipline profile.

We conducted these interviews primarily to understand the structural shape, procedural implementation and impact of quality management in teaching and learning. Many of our questions explicitly addressed the introduction, development and perceived effects of internal quality management on higher education. Hence, the interviewees provided us with information on how organizational change had taken place and what the main change drivers had been.

All interviews were audiotaped and transcribed verbatim. The interview data were qualitatively analysed through an iterative process of reading, coding and interpretation. The data analysis software MAXQDA was used to organize the interviews and to code data. In line with the theoretical approach, we coded respondents' answers as indicators of different sources and mechanisms of isomorphism. In accordance with DiMaggio and Powell (1983), our data was coded to measure coercive isomorphism if interview statements revealed external pressure exerted by legal demands or governmental regulations. The data referring to mimetic isomorphism indicated a high incidence of copying mentality in the respondents induced by the uncertainty of having to deal with ambiguity in the working environment. Finally, we coded normative isomorphism with processes of professionalization, implying accepted and welldefined methods, and by respondents' established formal education and professional networks.

In addition to the interview study, a nationwide survey was conducted by us between July and September of 2015. An online questionnaire was sent out to all public higher education institutions to identify staff responsible for quality management at the central management level (excluding faculty members in quality management). Thus, the survey reached the quality management departments and their functional equivalents in nearly all public higher education institutions in Germany. In total, 294 out of 639 identified quality managers responded to the questionnaire. This represents a response rate of $46 \%$, which is a comparatively good result for online surveys in the German context.

The survey and the development of particular items in the questionnaire were mostly based on the interviews with quality management staff. The questionnaire covered various topics regarding the adoption, implementation and perceived effects of quality management. In this context, the survey queried the reasons for the introduction of quality management, the role of higher education institutions' management in this process and the perceived effectiveness of quality management. As measuring effectiveness can be a complex and problematic task (Cameron and Whetten 1981), this study operationalized effectiveness as perceptions of effectiveness. We constructed most of the respective items on a six-point Likert-scale and respondents were asked to agree or disagree with certain statements. Table 1 shows the respective items and criteria considered for the quantitative analysis. 
Table 1 Criteria for quantitative analysis

\begin{tabular}{|c|c|c|}
\hline \multicolumn{2}{|l|}{ Category } & $\begin{array}{l}\text { Variables } \\
\text { Coercive }\end{array}$ \\
\hline Institutional Isomorphism & $\begin{array}{l}\text { Reasons for the introduction } \\
\text { of quality management }\end{array}$ & $\begin{array}{l}\text { Coercive } \\
\text { Regulations by state ministry } \\
\text { Bologna Process } \\
\text { Target agreements } \\
\text { Normative } \\
\text { Quality management networks } \\
\text { European standards } \\
\text { External consultation } \\
\text { Mimetic } \\
\text { Orientation towards other higher } \\
\quad \text { education institutions } \\
\text { Cooperation with other higher } \\
\text { education institutions }\end{array}$ \\
\hline Institutional Entrepreneurship & $\begin{array}{l}\text { higher education institution's } \\
\text { management }\end{array}$ & $\begin{array}{l}\ldots \text { is interested in quality management } \\
\ldots \text { supports quality management } \\
\ldots \text { declares quality management as priority } \\
\ldots \text { was responsible for the introduction } \\
\text { of quality management }\end{array}$ \\
\hline $\begin{array}{l}\text { Quality management } \\
\text { Effectiveness }\end{array}$ & Quality management & $\begin{array}{l}\ldots \text { is effective in teaching and learning } \\
\ldots \text { contributes to an improvement in teaching } \\
\text { and learning }\end{array}$ \\
\hline
\end{tabular}

\section{Empirical results}

To answer the main research question and to obtain the empirical results, we combined the qualitative and quantitative results for both institutional isomorphism and institutional entrepreneurship. We considered the adoption and the implementation of quality management in teaching and learning and found that both theoretical approaches were related to the perceived effectiveness of quality management.

\section{Adopting quality management in teaching and learning}

With regard to the adoption of quality management, quality managers emphasized in their interview statements the relevance of coercive pressure - but they also highlighted the role of leadership by higher education institutions' management. Hence, it appears that quality management has become a core mission of higher education institutions due to priorities set at higher management levels. For example, one quality manager stated:

And I cannot recall now exactly to what extent this was adapted. However, at that time, it was the foundation. Then, we did the target agreements where quality assurance was declared a core mission of the university and then eventually it was more and more emphasized. (FH5QM)

This quote exemplifies that quality management had become a core task not only because of existing target agreements but also because of a stronger focus on quality and quality assurance. Other quality managers highlighted the role of state higher education regulations that have led to the establishment of quality management. Thus, quality management is often 
perceived as a direct consequence of laws and also as an external duty to be implemented by higher education institution managers. Another respondent stated:

And then there were... frankly speaking, external drivers. First of all, the higher education law in the State of Rhineland-Palatinate required us to set up a quality assurance system... And if that is, one should - as a university management representative - take account of and follow the law in its latest version. At least that is my understanding of being a vice president... that, if the legislative power of the state requires me to do quality assurance, I have to follow. (FH1VP)

Although this quote does not reveal much about how quality management was established in this particular higher education institution, it underlines the relevance of the topic. In contrast to the relationship of coercion to leadership, other statements give hints regarding the relationship of mimetic isomorphism to leadership, as follows:

And, of course, it makes sense to observe what other universities are doing. For us, it was important - particularly, the introversive message is always important... to say 'Let's check first if that is good for us, before we go into the details without any detailed knowledge and experience' - and where would we have gathered it?... and to say 'This is good for us' or not, and instead approach it without any fixed expectations, to phrase it a bit offhand... Stating 'it's the law' is of course an argument which is used by the leadership but needs to be handled with care. (FH1VP)

The interviewee emphasizes that what other actors are doing should not be ignored. But this is not just a statement of copying and pasting structures or procedures. The quoted passage shows that actors were well aware of the need to develop their own solutions suited to their own particular context. Hence, the transfer of ideas and knowledge is an essential element for reducing uncertainty.

Besides these arguments, there are also indications for forms of normative isomorphism in connection with leadership. Some interviewees highlighted the 'quality fashion', which could also be interpreted as mimetic isomorphism and may have gained further support with a change in top management. Therefore, further developments were initiated, such as the preparation of accreditation or the introduction of an academic scorecard. As one respondent reported:

There was a new team, and the issue of quality was surely en vogue at that time. In addition to that, the constellation in the rectorate at that time was in favour of [quality management] which we wanted to develop. The process then was iterative and received a significant push from introducing the academic scorecard and institutional self-accreditation. (FH2VP)

Other interviewees clearly emphasized the role of standards as an impulse for the implementation of quality management. In the quotation below, the 'PDCA' cycle (plan-do-check-act) has been used as a narrative to implement procedures for ongoing improvement and reflection:

Well, I would say that the training we received from the CHE [Centre for Higher Education] was a strong impulse. There was the suggestion to apply and implement 
the PDCA model in our institution and we communicated this, introversively, a lot. Thus, I consider this to be a standard for quality management which we did not scrutinize very much. What seems to be reasonable about this model is that it pursues the idea of implementing a continuous process, and not having a firefighter-like system. (Uni12VP)

Two preliminary findings can be drawn from the qualitative data. First, isomorphic pressures and leadership were relevant for the establishment of quality management. Second, there seems to be strong interrelationships between isomorphism and leadership. Different forms of isomorphism are interpreted and exploited differently by higher education institution managers.

To obtain a general overview of the relevance of different forms of isomorphism, we subsequently analysed quantitative survey data. Quality managers were asked about the relevance of the main driving forces for the introduction of quality management (see Fig. 2).

The items that signalled coercive isomorphism were by far the most important reasons for the introduction of quality management in the higher education sector. This finding reflects the general belief that higher education institutions were compelled to introduce formalized quality management (Enders and Westerheijden 2014) by regulative requirements in the aftermath of the Bologna Process. In comparison, the items indicating normative isomorphism received lower agreement ratings. The respective distributions were centred in the middle of the scale. The results for mimetic isomorphism show similarly high figures. Interestingly, cooperation with other higher education institutions as well as quality management networks was not considered to be a significant reason for the introduction of quality management. However, the comparably high standard deviations signal that there are large differences in the respective assessments.

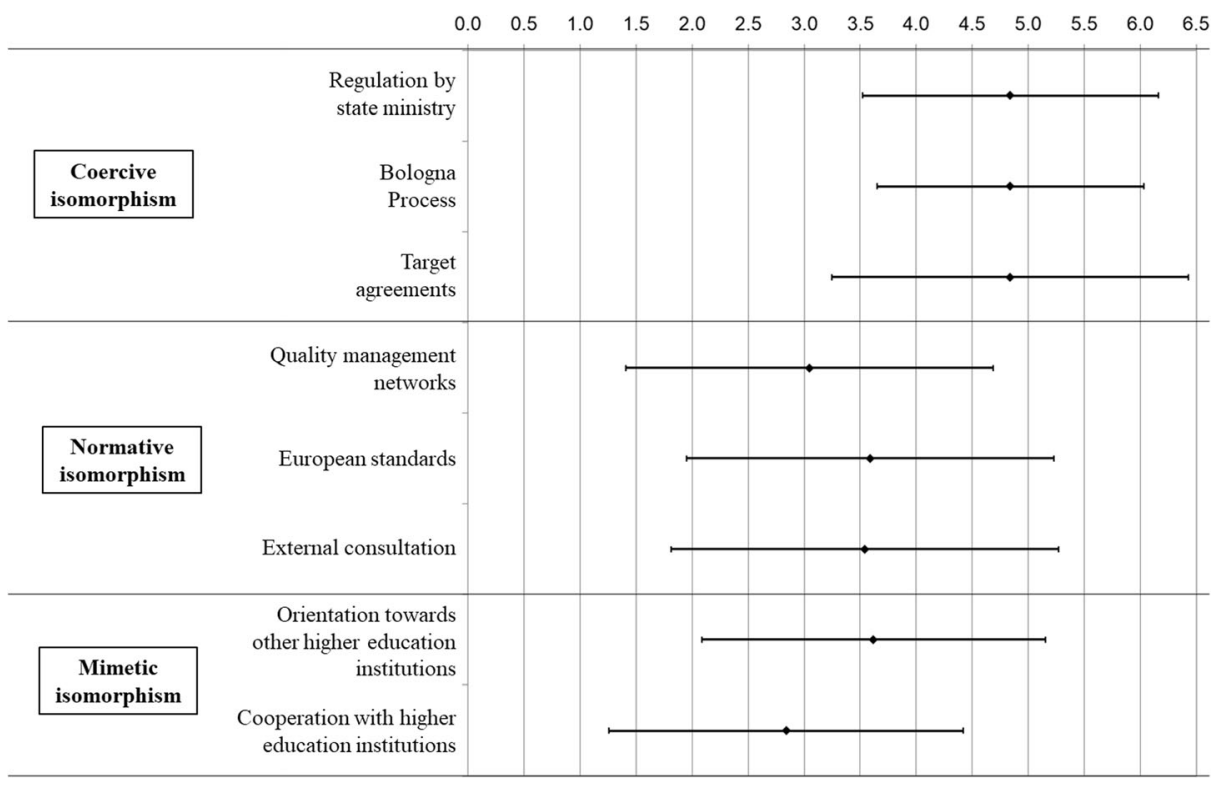

Fig. 2 Reasons for the introduction of quality management. Note: Scale from 1 to 6 (1 'very unimportant' to 6 'very important'), figure shows means $+/-$ one standard deviation from the mean. Source: Own data set 


\section{Implementation and perceived effectiveness of quality management in teaching and learning}

As outlined above, we were also interested in the role of higher education institutions' top management in quality management implementation. In comparison to the items above, it is striking that all of them articulated the importance and support of higher education institutions' management. Higher education institution leaderships' interest in quality management seems to be a shared interest. The item shows the strongest support and the lowest standard deviation (see Fig. 3). Less relevant is the prioritization of quality management as a core task of higher education institutions. However, this item reveals the largest standard deviation, which implies that there were some higher education institutions in which top-level management did not prioritize quality management. Nevertheless, the items underline higher education institutions' top management's overall support for quality management. All in all, this suggests that higher education institutions' management has played a helpful role in promoting quality management and implementing organizational change. Therefore, based on our theoretical argument, we infer that this institutional work provided a solid foundation for making quality management effective and impactful.

In summary, the quantitative data indicate that the different forms of isomorphic pressures and institutional entrepreneurship matter for the introduction and implementation of quality management. Regarding the reasons for the introduction of quality management, the results suggest an equal relevance for mimetic and normative isomorphism but a significantly higher relevance for coercive isomorphism. With respect to quality management implementation, the results imply that higher education institutions' management's interest in, and responsibility towards, quality management are very important. However, what are missing are the empirical linkages between institutional isomorphism, entrepreneurship and perceived effectiveness of quality management in teaching and learning.

$\begin{array}{llllllllllllll}0.0 & 0.5 & 1.0 & 1.5 & 2.0 & 2.5 & 3.0 & 3.5 & 4.0 & 4.5 & 5.0 & 5.5 & 6.0 & 6.5\end{array}$

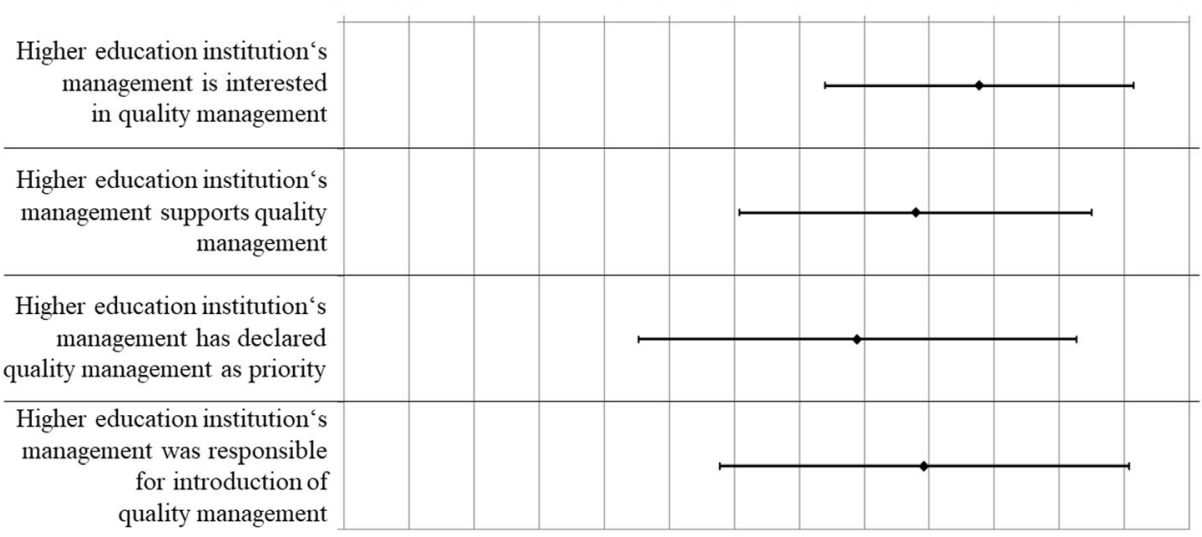

Fig. 3 The role of higher education institution's top management. Note: Scale from 1 to 6 (1 'not correct at all' to 6 'fully correct'), figure shows means +/- one standard deviation from the mean. Source: Own data set 


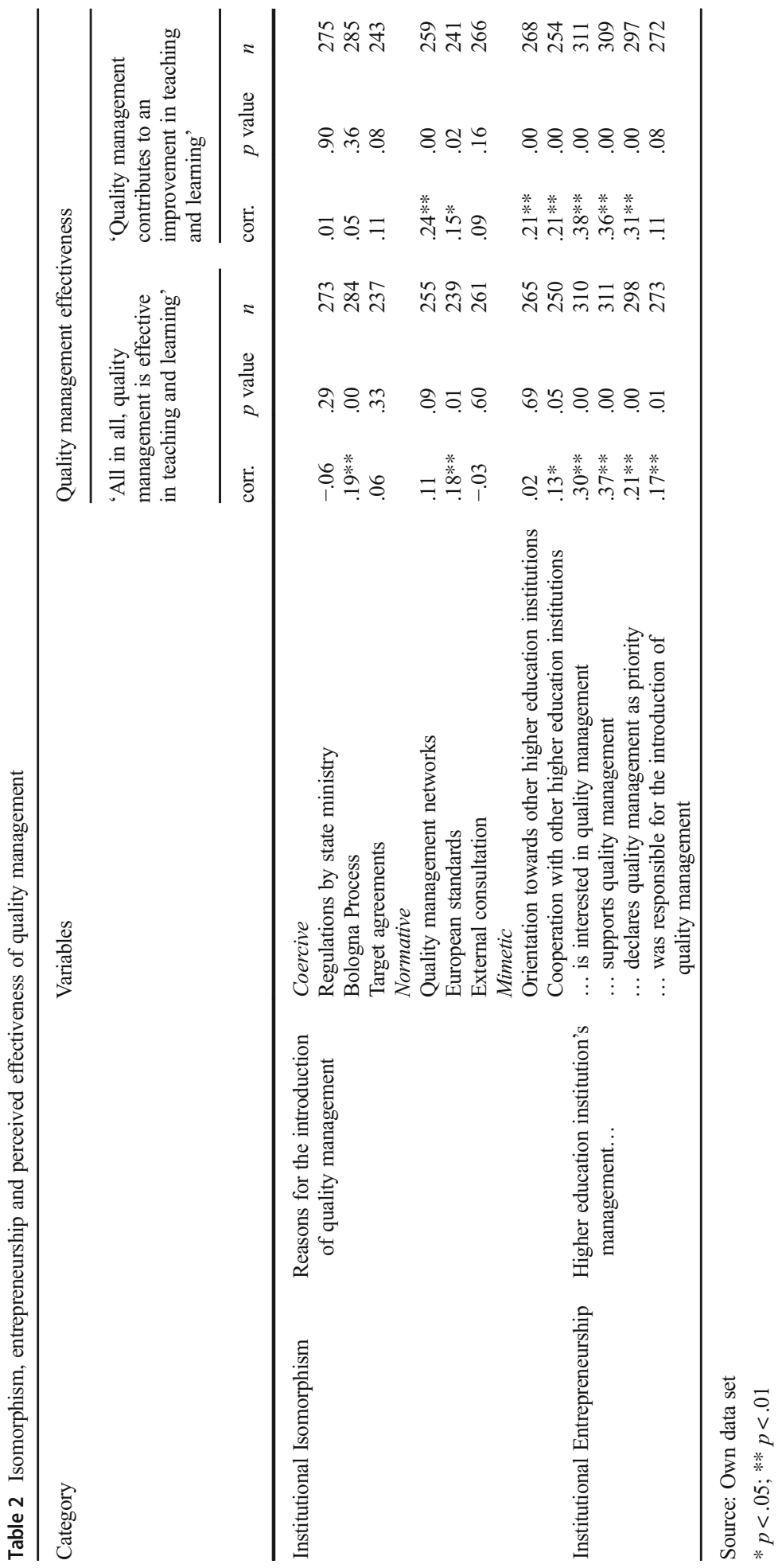


Finally, we investigated whether isomorphism and institutional leadership have an influence on the perceived effectiveness of quality management. We calculated bivariate correlations to examine the relationship between the variables. Table 2 shows weak but statistically significant correlations (between $p<.05$ and $p<.01$ ) among variables related to the independent variables isomorphism and institutional entrepreneurship, and positive substantial changes inspired by the perceived effectiveness of quality management.

With regard to isomorphism, the obtained results show rather weak but significant correlations with positive effects for normative and mimetic isomorphism and close to no correlation for coercive isomorphism. However, the item related to the Bologna Process did reveal a significant and positive correlation. This indicates that actors introduce quality management for various reasons, resulting in different implications for the perceived effects of the respective instruments, such as evaluations, surveys, and so on. For example, if quality management is adopted based on normative (or mimetic) institutional pressures, quality managers perceive that quality management contributes to the improvement of teaching and learning - but the overall assessment regarding the perceived effectiveness reveals scepticism. However, if quality management is introduced as compliance (coercion), there are no measurable positive effect for the relationship between quality management and compliance.

Nevertheless, we found comparatively stronger correlations for the relationships between entrepreneurship variables and the perceived improvement in teaching and learning. Except for the item that represented the role of entrepreneurship (higher education institutions' leadership was the central actor pushing quality management), all items correlated around $r=.30$ and higher. Based on the results, the most relevant item was higher education institutions' management's interest in quality management, followed by support and prioritization of quality management over other tasks and duties.

\section{Concluding discussion}

This paper empirically investigated the significance of institutional isomorphism in quality management adoption and institutional entrepreneurship in quality management implementation as factors influencing the perceived effectiveness of quality management in higher education. It should be stressed that this study provides evidence that is limited to the German context. Nevertheless, despite this limitation, we consider that the following main findings of our analysis may inspire future research.

First, the qualitative study provided empirical evidence regarding the influence of institutional pressure on quality management adoption. Quality management actors have consistently stressed the importance of coercive, mimetic and normative influences in this context.

Second, our quantitative results statistically validated that quality managers and management staff at higher education institutions did perceive that isomorphism affected quality management introduction. Although coercive isomorphism was the strongest form of isomorphism, mimetic and normative isomorphism were also perceived as relevant for quality management introduction. Interestingly, coercion showed the smallest correlations with variables that measured the perceived effectiveness of quality management in teaching and learning.

Third, while isomorphism was relevant for the introduction of quality management through external pressures, institutional entrepreneurship and leadership are important to understand its implementation. Thus, the empirical results indicate a supporting role for institutional entrepreneurship with regard to the introduction and establishment of quality management. While 
isomorphic pressures can be regarded as relevant for the introduction and the initial design of quality management, entrepreneurship is responsible for its further development and trajectory towards the specific needs of individual higher education institutions.

Fourth, we analysed the correlation between isomorphism and entrepreneurship items and the perceived effectiveness of quality management. The results showed that only coercive isomorphism failed to correlate with perceived effectiveness; this is not surprising, as coercive isomorphism denotes formal compliance without intrinsic motivation. Nevertheless, the results revealed the strongest correlations for the entrepreneurship items. Hence, if quality management in teaching and learning is supported by higher education institutions' leadership, and if higher education institutions' management shows interest in quality management, quality managers will perceive high levels of quality management effectiveness.

These findings are compatible with existing research exploring quality management in the broader context of how higher education institutions further develop. Quality management is an important step towards functional differentiation, professionalization and specialization (Ramirez and Christensen 2013, p. 702; Stensaker 2014, p. 108). These organization goals are important in order that higher education institutions' management teams can develop universities as 'formal organizations' (Ramirez and Christensen 2013, p. 706) with a 'quality organizational culture' (Hart and Schoolbred 1993, pp. 23-24). The results further indicate that actors within higher education institutions do not just respond to external demands in the usual and presumably chaotic way (e.g., garbage-can type of decision-making; Cohen et al. 1972). Instead, they very much try to internalize global trends and solutions for local problems (Paradeise and Thoenig 2013). Thus, bringing institutional isomorphism and institutional entrepreneurship together seems to be a very promising approach for future research, such as the integration of further theoretical perspectives and the translation approach (Sahlin and Wedlin 2008) and the perspective of actor-centred institutionalism (Scharpf 1997). These theories remind us that it is worth re-examining the complex relationship between institutions and agency in order to fully understand organizational behaviour.

Acknowledgements This work originates from the research project WiQu - Impact research on quality assurance of teaching and learning - procedural, structural and personnel causes of quality assurance departments' impact. It was supported by the German Federal Ministry of Education and Research (Bundesministerium für Bildung und Forschung) [grant number 49 01PY13003A].

Open Access This article is distributed under the terms of the Creative Commons Attribution 4.0 International License (http://creativecommons.org/licenses/by/4.0/), which permits unrestricted use, distribution, and reproduction in any medium, provided you give appropriate credit to the original author(s) and the source, provide a link to the Creative Commons license, and indicate if changes were made.

Publisher's Note Springer Nature remains neutral with regard to jurisdictional claims in published maps and institutional affiliations.

\section{References}

Barreto, I., \& Baden-Fuller, C. (2006). To conform or to perform? Mimetic behavior, legitimacy-based groups and performance consequences. Journal of Management Studies, 43(7), 1559-1581.

Battilana, J., Leca, B., \& Boxenbaum, E. (2009). How actors change institutions: Towards a theory of institutional entrepreneurship. The Academy of Management Annals, 3(1), 65-107. 
Birnbaum, R. (2000). The life cycle of academic management fads. The Journal of Higher Education, 71(1), 1-16. Cameron, K., \& Whetten, D. (1981). Perceptions of organizational effectiveness over organizational life cycles. Administrative Science Quarterly, 26, 525-544.

Cohen, M. D., March, J. G., \& Olsen, J. P. (1972). A garbage can model of organisational choice. Administrative Science Quarterly, 17(1), 1-25.

Csizmadia, T. G. (2006). Quality management in Hungarian higher education: Organizational responses to governmental policy. Enschede, Netherlands: CHEPS/University of Twente.

Csizmadia, T., Enders, J., \& Westerheijden, D. F. (2008). Quality management in Hungarian higher education: Organisational responses to governmental policy. Higher Education, 56(4), 439-455.

DiMaggio, P. J. (1988). Interest and agency in institutional theory. In L. D. Zucker (Ed.), Institutional patterns and organizations: Culture and environment (pp. 3-21). Cambridge: Ballinger.

DiMaggio, P. J., \& Powell, W. (1983). The iron cage revisited: Institutional isomorphism and collective action in organisational fields. American Sociological Review, 48(2), 147-160.

Enders, J., \& Westerheijden, D. F. (2014). Quality assurance in the European policy arena. Policy and Society, 33(3), 167-176.

Greenwood, R., \& Suddaby, R. (2006). Institutional entrepreneurship in mature fields: The big five accounting firms. Academy of Management Journal, 49(1), 27-48.

Greenwood, R., Oliver, C., Sahlin, K., \& Suddaby, R. (2008). Introduction. In R. Greenwood, C. Oliver, K. Sahlin, \& R. Suddaby (Eds.), SAGE handbook of organizational institutionalism (pp. 1-46). London: SAGE.

Hart, C., \& Schoolbred, M. (1993). Organisational culture, rewards and quality in higher education. Quality Assurance in Education, 1(2), 22-29.

Hirsch, P., \& Lounsbury, M. (1997). Ending the family quarrel: Toward a reconciliation of 'old' and 'new' institutionalisms. American Behavioral Scientist, 40, 406-418.

Kaufmann, B. (2009). Qualitätssicherungssysteme an Hochschulen: Maßnahmen und Effekte; Eine empirische Studie. Bonn, Germany: Hochschulrektorenkonferenz.

Kelle, U. (2006). Combining qualitative and quantitative methods in research practice: Purposes and advantages. Qualitative Research in Psychology, 3(4), 293-311.

Kraatz, M. S. (2009). Leadership as institutional work: A bridge to the other side. In T. B. Lawrence, R. Suddaby, \& B. Leca (Eds.), Institutional work: Actors and agency in institutional studies of organizations (pp. 59-91). Cambridge: Cambridge University Press.

Lawrence, T. B., \& Suddaby, R. (2006). Institutions and institutional work. In S. R. Clegg, C. Hardy, T. B. Lawrence, \& W. R. Nord (Eds.), Handbook of organization studies (pp. 215-254). London: SAGE.

Maguire, S., Hardy, C., \& Lawrence, T. B. (2004). Institutional entrepreneurship in emerging fields: HIV/AIDS treatment advocacy in Canada. Academy of Management Journal, 47, 657-679.

Martin, M., \& Parikh, S. (2017). Quality management in higher education: Developments and drivers. Results from an international survey. Paris, France: International Institute for Educational Planning/UNESCO. Retrieved from http://unesdoc.unesco.org/images/0026/002602/260226E.pdf. Accessed 5 Dec 2018.

Meyer, J. W., \& Rowan, B. (1977). Institutionalized organisations: Formal structure as myth and ceremony. American Journal of Sociology, 83(2), 340-363.

Mizruchi, M., \& Fein, L. (1999). The social construction of organizational knowledge: A study of the uses of coercive, mimetic, and normative isomorphism. Administrative Science Quarterly, 44(4), 653-683.

Paradeise, C., \& Thoenig, J.-C. (2013). Academic institutions in search of quality: Local orders and global standards. Organization Studies, 34(2), 189-218.

Pohlenz, P., \& Seyfried, M. (2014). Die Organisation von Qualitätssicherung. Heterogene Studierende, vielfältige Managementansätze. Die Hochschule, 24(2), 144-155.

Ramirez, F. O., \& Christensen, T. (2013). The formalization of the university: Rules, roots and routes. Higher Education, 65(6), 695-708.

Rhoades, G., \& Sporn, B. (2002). Quality assurance in Europe and the U.S.: Professional and political economic framing of higher education policy. Higher Education, 43(3), 355-390.

Sahlin, K., \& Wedlin, L. (2008). Circulating ideas: Imitation, translation and editing. In R. Greenwood, C. Oliver, R. Suddaby, \& K. Sahlin (Eds.), The SAGE handbook of organizational institutionalism (pp. 218-242). Los Angeles: SAGE.

Sandelowski, M. (2000). Focus on research methods. Whatever happened to qualitative description? Research in Nursing \& Health, 23(4), 334-340.

Scharpf, F. W. (1997). Games real actors play: Actor-centered institutionalism in policy research. Boulder: Westview Press.

Schimank, U., \& Lange, S. (2009). Germany: A latecomer to new public management. In C. Paradeise, E. Reale, I. Bleiklie, \& E. Ferlie (Eds.), University governance: Western European comparative perspectives (pp. 5175). Berlin: Springer.

Selznick, P. (1957). Leadership in administration: A sociological interpretation. Berkeley: University of California Press. 
Seyfried, M., \& Ansmann, M. (2018). Unfreezing higher education institutions? Understanding the introduction of quality management in teaching and learning in Germany. Higher Education, 75(6), 1061-1076.

Soomro, T. R., \& Ahmad, R. (2012). Quality in higher education: United Arab Emirates perspective. Higher Education Studies, 2(4), 148-152.

Stensaker, B. (2007). Quality as fashion: Exploring the translation of a management idea into higher education. In D. F. Westerheijden, B. Stensaker, \& M. J. Rose (Eds.), Quality assurance in higher education: trends in regulation, translation and transformation (pp. 99-118). Dordrecht: Springer.

Stensaker, B. (2008). Outcomes of quality assurance: A discussion of knowledge, methodology and validity. Quality in Higher Education, 14(1), 3-13.

Stensaker, B. (2014). Organisational identity as a concept of understanding university dynamics. Higher Education, 69(1), 103-115.

Tashakkori, A., \& Teddlie, C. (2003). Handbook of mixed methods in social \& behavioral research. Thousand Oaks: SAGE.

Washington, M., Boal, K. B., \& Davis, J. N. (2008). Institutional leadership: Past, present, and future. In R. Greenwood, C. Oliver, R. Suddaby, \& K. Sahlin (Eds.), The SAGE handbook of organizational institutionalism (pp. 721-735). Los Angeles: SAGE.

Westphal, J. D., Gulati, R., \& Shortell, S. M. (1997). Customization or conformity? An institutional and network perspective on the content and consequences of TQM adoption. Administrative Science Quarterly, 42, 366-394.

Woodhouse, D. (1996). Quality assurance: International trends, preoccupations and features. Assessment \& Evaluation in Higher Education, 21(4), 347-356. 